\title{
Sýn Íslendinga á utanríkis- og öryggismál
}

\author{
Silja Bára Ómarsdóttir, PhD, ađjunkt við Stjórnmálafræđideild, Háskóli Íslands
}

\begin{abstract}
Útdráttur
Afstaða Íslendinga til öryggismála hefur lítið verið rannsökuð frá pví í lok kalda stríðsins. Í pessari grein eru kynntar niðurstöður könnunar um afstöðu til og hugmyndir um utanríkis- og öryggismál, en Félagsvísindastofnun HÍ vann könnunina í nóvember og desember 2016. Niðurstöður könnunarinnar eru settar í samhengi við próun í öryggisfræðum, pá sérstaklega öryggisgeira (e. security sectors) verufræðilegt öryggi (e. ontological security) og öryggisvæðingu (e. securitization). Helstu niðurstöður eru að almenningur á Íslandi telur öryggi sínu helst stafa ógn af efnahagslegum og fjárhagslegum óstöðugleika og náttúruhamförum, en telur litlar líkurá pvíað hernaðarátök eða hryðjuverkaárásir snerti landið beint. Dessar niðurstöður eru í takmörkuðu samræmi við helstu áherslur stjórnvalda í öryggismálum og pví mikilvægt að stjórnvöld átti sig á pví hvernig hægt er að tryggja pað að almenningur sé meðvitaður um pær forsendur sem áhættumat og öryggisstefna grundvallast á.
\end{abstract}

Efnisorð: Ísland; utanríkismál; öryggismál; verufræðilegt öryggi.

\section{Icelanders' perspectives on security and foreign affair}

\section{Abstract}

Icelanders' views on security and foreign affairs since the end of the Cold War are an understudied issue. This article presents the findings of a large scale survey on the position and ideas about foreign affairs and security. The survey was conducted by the Social Science Research Institute of the University of Iceland in November and December 2016. The results of the survey are placed in the context of developments in security studies, with an emphasis on security sectors, ontological security, and securitization. The main findings are that the

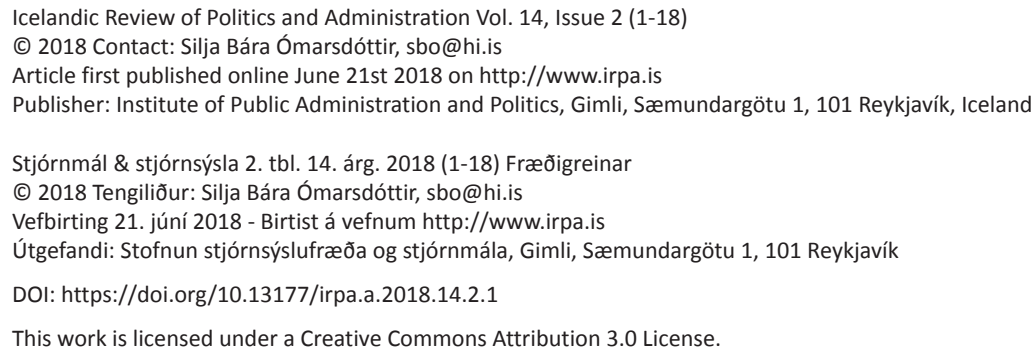


Icelandic public believes that its security is most threatened by economic and financial instability, as well as natural hazards, but thinks there is a very limited chance of military conflict or terrorist attacks directly affecting the country. These findings are incongruent with the main emphases of Icelandic authorities, as they appear in security policy and political discourse. It is therefore important that the authorities understand how to engage with the public about the criteria upon which risk assessments and security policies are based.

Keywords: Iceland; securitization; terrorism; ontological security.

\section{Inngangur}

Öll ríki heims purfa að huga að öryggi sínu og borgara sinna. Frá pví fullvalda ríki urðu til hefur pað verið ein af grundvallarskilgreiningunum á ríkjum, að pau hafi einkarétt á valdbeitingu og geti notað vald til pess að verja borgarana fyrir ógnum sem aðrir borgarar skapa peim. Einkum og sér í lagi ber ríkinu að tryggja ytra öryggi með pví að verja landamæri ríkisins. Fyrir hin örfáu ríki heims sem ekki hafa her er flóknara að nálgast petta hlutverk en par sem herir eru starfandi. Á Íslandi var öryggi ríkisins við fullveldi tryggt með hlutleysi, sem í sambandslögunum stóð að skyldi vera ævarandi. Dað var pó ekki langlífara en svo að Ísland varð stofnaðili að Atlantshafsbandalaginu (NATO) árið 1949 og varla hefur komið til álita af hálfu stjórnvalda að slíta peirri aðild síðan. Í pessu felst pó ekki að full sátt ríki um aðildina, eða jafnvel að almenningur hafi fullan skilning á pví hvað felst í henni. Pá hefur lítið verið rannsakað hvað pað er sem almenningur telur að skapi öryggi. Dessi grein kynnir niðurstöður könnunar á pví hvernig íslenskur almenningur skynjar öryggi landsins og pær ógnir sem að pví steðja.

Greinin hefst með stuttri fræðilegri umræðu um nýlegar breytingar í öryggisfræðum (e. security studies) par sem öryggi hefur ekki einungis verið víkkað og dýpkað með pví að gera grein fyrir öryggi á grundvelli efnahags, náttúru og samfélags, heldur opnað fyrir pátttöku almennings í mótun og viðhaldi stefnu. Hér er nauðsynlegt að gera grein fyrir öryggisvæðingu og hvernig hún fer fram, og pví hvernig almenningur getur svarað öryggisvæðingartilburðum valdhafa. Pá er rætt um verufræðilegt öryggi (e. ontological security), sem felst í pví að skoða hvernig sjálfsmynd og viðhald hennar getur spilað inn í pað hvernig almenningur skynjar og bregst við öryggisvæðingu og -ógnum. Einnig er öryggisstefna íslenska ríkisins kynnt, með áherslu á pað hvernig öryggisgeirar birtast í henni. Að lokinni fræðilegri umræðu er stutt umræða um aðferðafræði rannsóknarinnar sem hér er lögð til grundvallar og er hún svo kynnt. Rannsóknin var unnin í samvinnu við Félagsvísindastofnun Háskóla Íslands og lögð fyrir allan netpanel hennar í nóvember og desember 2016 og svöruðu 4848 af 8247 sem fengu hana senda. Könnunin var í heild 18 spurningar um alljóðamál, en hér er byggt á fjórum peirra, sem hverfast allar um afstöðu til utanríkis- og öryggismála.

Helstu niðurstöður mínar eru að almenningur á Íslandi hafi ekki mikla tilfinningu fyrir pví að öryggi sínu sé ógnað. Helstu ógnir sem almenningur skynjar eru efnahagsog fjárhagslegur óstöðugleiki og náttúruhamfarir. Niðurstöður könnunarinnar sýna að ótti við vopnuð átök eða hryðjuverk er lítill meðal landsmanna. Í öryggisstefnu fyrir 


\section{STJÓRNSÝSLA}

Ísland er hins vegar mun meiri áhersla lögð á hernaðarlegar ógnir, pótt forgangsröðun hafi breyst nokkuð í meðförum pingsins og pá meira í átt að peirri skynjun almennings sem birtist hér.

\section{1. Öryggi: Kenning og veruleiki}

Í pessum kafla er farið yfir fræðilegan grunn rannsóknarinnar, sem byggist á hugmyndum um öryggisgeira, öryggisvæðingu og verufræðilegt öryggi. Undirliggjandi öllum pessum nálgunum er hugmyndin um samspil valdhafa og almennings í mótun ógna og öryggis innan samfélaga, sem og tilraunir almennings til að halda í sjálfsmynd sína í gegnum venjur og hefðir. Í öryggisfræðum var lengst af einblínt á öryggi ríkisins, með sérstakri áherslu á ytra öryggi pess, p.e. hvernig væri hægt að verjast hernaðarárásum af hálfu annarra ríkja. Frá pví undir lok kalda stríðsins hafa rannsóknir hins vegar beinst æ meira að öðrum páttum, sem gjarnan er nálgast á grundvelli hugmynda um öryggisgeira (e. security sectors) sem Buzan (1991) skilgreindi sem hernað, stjórnmál, umhverfi, efnahag og samfélag. Buzan, Wæver og deWilde (1998) unnu frekar með pessar nálganir og bættu við hugmyndinni um öryggisvæðingu (e. securitization), sem felst í pví að valdhafar skilgreina berum orðum ógn við tiltekið öryggisviðfang (e. referent object) og krefjast um leið réttar til að beita óhefðbundnum leiðum til að bregðast við ógninni. Eins og Wæver segir, pá krefjast pessar leiðir gjarnan hegðunar sem fylgir ekki reglum stjórnmálanna og heimila pví ríkinu að krefjast sérstakra réttinda (Wæver 1998). Með pví að yrða kröfur sínar um að tilteknar ógnir verði flokkaðar sem ógnir við öryggi landsins er ríkið að fara fram á pað að almenningur bregðist við og heimili öryggisvæðingu pessara ógna. Wæver bendir á að oftast sé spurt hvað sé verið að verja eða hverju(m) sé ógnað pegar petta fer fram, en sjaldnast hvort pað eigi í raun að setja pessa hluti í öryggissamhengi (Wæver 1998). Pað purfi pó að gera pví að erfitt sé að vinda ofan af öryggisvæðingu pegar hún hefur átt sér stað.

Browning og Joenniemi (2016) benda á að öryggi snúist ekki einungis um efnislegt öryggi heldur einnig skynjað. Krafan um að við upplifum okkur örugg er orðin svo sterk að „raunverulegu“ öryggi er jafnvel fórnað pegar við reynum að verja sjálfsmynd okkar og tryggja pannig verufræðilegt öryggi (e. ontological security). Detta birtist í peim venjum og siðum sem viðhalda sjálfsmynd okkar (Delehanty \& Steele 2009) og snýst um að verja hina huglægu mynd okkar af okkur sjálfum frekar en einungis líkamlegt öryggi. Mikilvægi verufræðilegs öryggis birtist hvað skýrast í pví að ef pví er ógnað brotnar sjálfsmynd og pað grefur undan félagslegum stöðugleika (Mitzen 2006). Verufræðilegt öryggi vísar til getu einstaklingsins til að athafna sig á grundvelli stöðugrar sjálfsmyndar í hversdagslegum athöfnum (Steele 2005), og snýst pví bæði um huglægt og hlutlægt mat á öryggi. Dess vegna er gjarnan vísað til sjálfsmyndar pegar óvissuástand ríkir (Kinnvall 2004) enda auðveldar sterk sjálfsmynd gerendum að raungera öryggi sitt (Flockhart 2012).

Browning og Joenniemi (2016) nefna einnig að pegar krafan um verufræðilegt öryggi - eða félagslegan stöðugleika - er hvað sterkust, pá geti pað verið á kostnað fjölbreytileika og gagnrýninnar umræðu. Đetta leiðir aftur að öryggisvæðingu, en oft er pví haldið 
fram að pegar tilraunir í pá átt eru gerðar skapist krafa á almenning að skipa sér á bak við stjórnvöld til að verjast hinni meintu utanaðkomandi ógn. Öryggisvæðing á sér alltaf stað í afmörkuðu rými og skapast pegar ógn, hvort sem hún felst í fólki, vopnum, sýklum eða öðru, kemst á hreyfingu. Almennt er talið að hún felist í pví að magna upp ótta og koma sér pannig hjá opinni umræou. Barnett bendir hins vegar á að einnig megi líta á öryggisvæðingu sem tækifæri til að endurmeta skammlífar reglur samfélagsins og að ekki sé alltaf um pað að ræða að stjórnvöld vilji víkja sér undan reglum lýðræðisins eða brjóta gegn gildum samfélags (Barnett 2015).

Oftast eru pað stjórnvöld sem hafa umboð til að skilgreina ógnir og stöðu til að raungera pær í gegnum málgjörðir (e. speech acts) og kalla pannig fram viðbrögð. McDonald nefnir hins vegar að pað sé of pröng sýn á öryggisvæðingu, pví hún geti einnig farið fram í gegnum sjónrænar eða efnislegar athafnir. Pá er mikil áhersla á pað í eldri rannsóknum á öryggisvæðingu að málgjörðin sé skyndileg, en McDonald telur hana geta verið stigvaxandi (McDonald 2008). En hvernig sem öryggisvæðing á sér stað, pá hafa flestar skilgreiningar á öryggi miðast við stöðu valdhafa og einblína gjarnan á öryggi ríkisins. Jaðarsettir hópar hafa pví ekki sama aðgang að pví að skilgreina ógnir við öryggi sitt, eins og Hansen (2000) bendir á pegar hún segir að ekki sé hægt að færa óöryggi í orð og pví purfi að huga að pví að pessi sömu skref megi oft finna í pögn. Petta bendir til pess að ekki einungis eigi almenningur erfiðara með аð skilgreina ógnir við öryggi sitt, heldur sé pað sérstaklega vandasamt fyrir undirskipaða hópa í samfélaginu að koma sínum skilgreiningum á framfæri, hvað pá að taka sér stöðu til að öryggisvæða pær ógnir. Huysmans nefnir einmitt að öryggi berist frá peim sem nefna pað til peirra sem heyra, en pað purfi að endurtaka hugmyndirnar til að sjá hvort pær séu meðteknar eða peim hafnað (Huysmans 2011). Pau sem ekki hafa völd í samfélaginu geta pví síður skilgreint öryggi fyrir sig eða haft áhrif á pað hvernig öryggi er skilgreint fyrir samfélagið. Hér bætir Sjöstedt pví við að setja purfi skilgreiningar á ógnum í samhengi. pær megi ekki líta á sem fastmótað fyrirbæri pví pað yfirskyggi mikilvæga pætti í mótun ógna (Sjöstedt 2013). Pannig voru vörubílar ekki ógn við öryggi fyrr en eftir að slíku tæki var beitt til að keyra niður almenna borgara á göngugötu í Nice (BBC News 2016) og svartir líkamar voru gerðir ógnvekjandi á Vesturlöndum pegar ebólufaraldurinn í Vestur-Afríku stóð sem hæst árið 2014 (Giorgis 2014; Omoleke, Mohammed \& Saidu 2016). Dá má nefna að kjúklingur og annað fiðurfé var öryggisvætt í kringum fuglaflensufaraldra (Centers for Disease Control and Prevention 2017). Hér parf að hugsa um pað hvernig ótti er vakinn meðal viðtakenda, en Van Rythoven (2015) telur að kafa purfi mun dýpra í pað ferli. Hann telur að ef hömlum sé komið á pað hvernig ótti er skapaður pá verði öryggisvæðingarferlið erfiðara fyrir valdhafa.

Öryggi er pví ekki einfaldlega fjarvera ógna eins og mætti halda, heldur skiptir máli hvernig pessar ógnir eru skilgreindar og hver hefur umboð til að gera pað. Dví má ekki horfa á öryggi og óöryggi sem andstæðupar, heldur leið til pess að sjá hvort gripið hafi verið til einhverra aðgerða til að setja tiltekna ógn fram í öryggissamhengi. Hér bendir Wæver (1998) á að búi fólk við fullkomið öryggi pá hafi pað ekki tilhneigingu til að skilgreina pað sem slíkt - pað er einfaldlega óparfi að orða pað undir peim kringumstæðum. 
Taureck (2006) bætir pví við að með öryggisvæðingarkenningum sé einfaldlega verið að reyna að svara spurningunni „hvað gerir öryggi“? Hér er einmitt reynt að varpa ljósi á pað hvort almenningur á Íslandi hugsi um tilteknar ógnir í samhengi við öryggi sitt eða hafi tilhneigingu til að hugsa ekki um öryggi yfir höfuð. Áður en pað er rætt er pó rétt að skoða hvernig íslenska ríkið nálgast öryggi í nýlegri stefnu sem staðfest var á Alpingi.

Alpingi sampykkti öryggisstefnu fyrir Ísland í apríl 2016. Stefnan hafði verið í vinnslu um töluvert skeið, en starfið hófst pegar Össur Skarphéðinsson skipaði pverpólitíska pingmannanefnd undir forystu Valgerðar Bjarnadóttur (mbl.is 2012) til að móta stefnu á grundvelli tillagna áhættumatsnefndar, en hún hafði skilað tillögum af sér 2009 (Utanríkisráðuneyti 2009). Pingmannanefndin skilaði sínum tillögum í febrúar 2014 og eftir langa mæðu var stefnan sampykkt á pingi vorið 2016. Í tillögum pingmannanefndar var megináhersla lögð á umhverfisógnir, en tillögur ráðherra drógu töluvert úr peirri áherslu. par voru fyrstu fjögur áhersluatriðin umhverfis- og öryggishagsmunir á Norðurslóðum, aðild að Atlantshafsbandalaginu, tvíhliða varnarsamningur við Bandaríkin og norræn samvinna um öryggis- og varnarmáláhersluatriðin, prátt fyrir að í skýringum hafi umhverfisvá, náttúruhamfarir og netógnir verið nefnd sem „pær hættur sem nefndin telur аð helst beri að setja í forgang“" (Vefútgáfa Alpingistíðinda 2016). Umhverfisáherslur voru takmarkaðar og aðallega nefndar af minnihlutanum á pingi. Tvö atriði mætti segja að féllu undir samfélagslegt öryggi. Annars vegar var pað fimmti liður tillögunnar, par sem fjallað var um virkt alpjóðasamstarf ,á grundvelli alpjóðalaga og með friðsamlega lausn deilumála, afvopnun, virðingu fyrir mannréttindum og réttarríkinu, jafnrétti kynjanna og baráttu gegn ójöfnuði, hungri og fátækt að leiðarljósi“ (Vefútgáfa Alpingistíðinda 2016), og hins vegar áttundi liður, um netöryggi. Í meðförum pingsins var fimmti liður færður fremst, til að leggja áherslu á pau mál sem par koma fram. Einnig var bætt við nýjum lið, par sem tekið er fram að stefna í almannavarna- og öryggismálum skuli vera hluti af pjóðaröryggisstefnu, „og par verði tekið mið af ógnum sem tengjast loftslagsbreytingum, náttúruhamförum, fæðu- og matvælaöryggi, heilbrigðisöryggi og farsóttum“ (Vefútgáfa Alpingistíðinda 2016). Stefnan endurspeglar pví breiða sýn á öryggi, sem er nálgast út frá hernaðarlegu og pólitísku öryggi, umhverfi og samfélagi. Engin umræða var pó um aðkomu almennings í mótun stefnunnar eða pátttöku í pví að koma henni í framkvæmd. Engar vísbendingar voru heldur um að stefnan ætti að mæta pörfum almennings, hvernig svo sem pær væru skilgreindar.

\section{Aðferð og gögn}

Pessi grein kynnir niðurstöður skoðanakönnunar sem lögð var fyrir á vegum Félagsvísindastofnunar Háskóla Íslands í nóvember og desember 2016. Könnunin var send á allan netpanel Félagsvísindastofnunar, eða 8.247 manns. Í heild svöruðu 4.848 einstaklingar könnuninni að hluta, en margir slepptu pví að svara einhverjum spurningum. Í könnuninni voru alls 18 spurningar fyrir utan bakgrunnsbreytur og snerust pær allar um utanríkis- og alpjóðamál á einhvern hátt. Hér er eingöngu rætt um fjórar spurningar sem tengjast skynjun almennings á og afstöðu til utanríkis- og öryggismála. Sett er fram lýsandi tölfræði, sem varpar ljósi á forgangsröðun varðandi helstu ógnir, afstöðu til full- 
yrðingar um meint hlutleysi Íslands, og loks mat á pví hvaða einkenni á ríkinu eða hvers konar alpjóðasamkomulag stuðlar helst að öryggi ríkisins, og rætt er um breytileika í afstöðu á grundvelli ýmissa bakgrunnsbreyta.

Spurningarnar sem um ræðir voru próaðar í samstarfi við starfsfólk Félagsvísindastofnunar í peim tilgangi að ná að varpa ljósi á afstöðu almennings til utanríkis- og öryggismála. Til grundvallar lá umfangsmikil eigindleg rýnihóparannsókn sem náði til 24 ólíkra hópa úr ólíkum áttum, alls um 250 manns (Ómarsdóttir 2017). Markmið peirrar rannsóknar var að öðlast innsýn í pað hvernig almenningur skynjar öryggi sitt, hvaða ógnir eru taldar steðja að einstaklingum, samfélagi og ríki og hvaða stofnanir eða alpjóðafyrirkomulag stuðli helst að öryggi pessara aðila. Í greiningu á peim gögnum kom fram ákveðin flokkun ógna, p.e. pólitískar og hernaðarlegar, samfélagslegar (p. á m. efnahagslegar) og umhverfislegar. Á grundvelli pessarar greiningar voru ellefu atriði skilgreind og notuð í röðunarspurningunum, par sem pátttakendur voru beðnir að forgangsraða eftir pví hvað peir teldu að ógnaði helst öryggi sínu og fjölskyldna sinna annars vegar og öryggi ríkisins hins vegar.

Í framangreindum rýnihópum kom fram ákveðinn misskilningur margra pátttakenda á hernaðarlegri stöðu Íslands, og virtust margir vera peirrar skoðunar að Ísland væri hlutlaust í hernaðarmálum. Pví var ákveðið að setja inn fullyrðingu pess efnis, sem pátttakendur voru beðnir að taka afstöðu til. Loks var ljóst af greiningu rýnihópaviðtalanna að ýmsir alpjóðasamningar, -stofnanir og einkenni ríkisins voru meðal pess sem almenningur taldi helst tryggja öryggi pess. Pess vegna var sett inn spurning um pað hvaða atriði pátttakendur teldu helst gera pað, og var boðið upp á sex valkosti við peirri spurningu. Í næsta kafla er fjallað um niðurstöður pessarar könnunar, en sökum pess hve stórt úrtakið var er vert að nefna að munurinn á milli hópa er tölfræðilega marktækur í öllum tilvikum.

\section{Sýn Íslendinga á alpjóða- og öryggismál}

Mjög fáar rannsóknir hafa verið gerðar á afstöðu Íslendinga til utanríkis- og öryggismála á síðustu árum. Á dögum kalda stríðsins vann Öryggismálanefnd, sem starfaði 1978-1991, ýmsar kannanir á afstöðu almennings til veru Bandaríkjahers á Miðnesheiði, m.a. eina par sem spurt var sérstaklega um afstöðu til utanríkis- og öryggismála (Hardarson 1985). Đá voru spurningar í íslensku kosningarannsókninni (ICENES) um afstöðu svarenda til aðildar ríkisins að Atlantshafsbandalaginu og herstöðvarinnar, en pær spurningar voru aflagðar eftir að Bandaríkjaher fór frá landinu haustið 2006 (Íslenska kosningarannsóknin e.d. - sjá t.d. spurningalista 2003 og 2007). Til skamms tíma fylgdust Samtök iðnaðarins grannt með afstöðu almennings til aðildar að Evrópusambandinu (Ómarsdóttir \& Elínardóttir 2010) en pær kannanir eru hvorki framkvæmdar lengur né snertu beint á öryggismálum. Рað eru pví til stöku gagnapunktar um afstöðu Íslendinga til utanríkis- og öryggismála, en ekki hefur verið fylgst reglubundið með henni. Könnunin sem pessi grein byggir á er tilraun til að breyta pví og skapa forsendur til að fylgjast með breytingum til lengri tíma.

Í könnuninni voru pátttakendur beðnir að taka afstöðu til eftirfarandi yfirlýsinga eða spurninga: 


\author{
Ísland er hlutlaust í hernaðarmálum \\ Hvað telur pú helst ógna öryggi Íslands? \\ Hvað telur pú helst ógna öryggi pínu og fjölskyldu pinnar? \\ Hvað telur pú að tryggi helst öryggi Íslands?
}

Pátttakendur voru beðnir að svara fullyrðingunni um hlutleysi Íslands eftir pví hversu sammála eða ósammála henni peir væru. Spurningarnar um ógnir við öryggi ríkisins og einstaklinga innihéldu ellefu valkosti sem hægt var að raða eftir mikilvægi. Valkostirnir voru farsóttir og heimsfaraldur, fjárhagslegt öryggi/fjármálakreppa, fólksflutningar, hryðjuverk, kjarnorkuvá, náttúruhamfarir, netárásir, persónulegt ofbeldi, skipulögð glæpastarfsemi, umhverfisvá og loftslagsbreytingar og loks vopnuð átök. Loks voru pátttakendur beðnir að svara pví hvaða alpjóðlegu pættir tryggðu helst öryggi Íslands, og purftu par að velja á milli sex kosta, sem aftur eru byggðir á niðurstöðum eigindlegrar rannsóknar minnar á skynjun almennings á öryggi og áherslum stjórnmálamanna í umræðum um öryggismál á Alpingi. Valkostirnir hér voru: Herleysi, friðsamleg tengsl við nágrannaríki, smæð ríkisins og að pað ógni engum, aðild að Atlantshafsbandalaginu, önnur vestræn samvinna, og að lokum aðild að Schengen-samstarfinu. Hér verður farið yfir niðurstöður fyrir hverja spurningu fyrir sig.

\title{
3.1 Meint hlutleysi Íslands
}

Рað kann að koma spánskt fyrir sjónir að biðja Íslendinga um að taka afstöðu til hlutleysis, en í eigindlegu rannsókninni sem pessar spurningar byggjast á kom oft fram að pátttakendur par töldu Ísland vera hlutlaust pegar kæmi að hernaðarmálum. Með pessu fylgir ályktunin um að Ísland purfi ekki að hafa áhyggjur af pví að taka pátt í alpjóðlegum átökum á neinn máta, eða að ríkið njóti verndar vegna pessa meinta hlutleysis. Đá spilar hugmyndin um hlutleysi eflaust einnig pátt í pví að fólk telji ólíklegt að Ísland verði skotmark hryðjuverkahópa. Í viðtölunum mátti skynja að pessi (mis)skilningur byggðist á pví að fólk blandaði saman herleysi landsins og hugmyndinni um hlutleysi, en til pess að skilja betur hvernig hugmyndir um öryggismál eru mótaðar parf að hafa skilning á pessari afstöðu.

prátt fyrir að í kjölfar viðtalanna hafi verið talið nauðsynlegt að kanna hvort pessi skilningur væri almennur meðal Íslendinga, pá kom á óvart hversu almennur hann er. Tafla 1 sýnir að 44\% svarenda eru mjög eða frekar sammála pví að Ísland sé hlutlaust í hernaðarmálum. Konur eru líklegri en karlar til að telja svo vera, 47\% peirra eru sammála fullyrðingunni en engu að síður eru 42\% karla sama sinnis. Pá telja 52\% peirra sem eru undir prítugu að Ísland sé hlutlaust. Раð væri auðvelt að ætla að útskýra pessa afstöðu með pekkingarleysi yngri kynslóðarinnar sem hefur alist upp eftir að kalda stríðinu lauk, en pá bregður svo við að 46\% peirra sem eru yfir sextugu eru sama sinnis, sem og $40 \%$ peirra mest menntuðu.

Nokkur breytileiki er milli hópa hvað varðar tekjur og pau sem hafa lægri tekjur eru líklegri til að telja að Ísland sé hlutlaust. Mesta breytileikann má hins vegar greina á 
grundvelli stjórnmálaskoðana. Dar eru kjósendur Sjálfstæðisflokksins og Framsóknarflokks verst upplýstir, ef svo má segja, en 52\% og 54\% peirra telja að Ísland sé hlutlaust. Kjósendur Viðreisnar eru ekki langt í burtu, en 46\% peirra telja Ísland hlutlaust. Björt framtíð, Píratar og Vinstrihreyfingin - grænt framboð og kjósendur annarra flokka eru svo í einu mengi; $40 \%$ og 41\% peirra taka undir pessa fullyrðingu. Hins vegar eru kjósendur Samfylkingarinnar best upplýstir um petta, pótt ríflega priðjungur peirra telji Ísland vera hlutlaust.

Tafla 1. Hlutleysi Íslands í hernađarmálum

\begin{tabular}{|c|c|c|c|c|c|c|c|c|}
\hline & $\begin{array}{c}\text { Mjög } \\
\text { sammála }\end{array}$ & $\begin{array}{l}\text { Frekar } \\
\text { sammála }\end{array}$ & $\begin{array}{c}\text { Hvorki } \\
\text { sammála né } \\
\text { ósammála }\end{array}$ & $\begin{array}{c}\text { Frekar } \\
\text { ósammála }\end{array}$ & $\begin{array}{c}\text { Mjög } \\
\text { ósammála }\end{array}$ & $\begin{array}{l}\text { Fjöldi } \\
\text { eftir } \\
\text { vigtun }\end{array}$ & $\begin{array}{l}\text { Fjöldi } \\
\text { fyrir } \\
\text { vigtun }\end{array}$ & Mjög eða frekar sammála \\
\hline Heild & $8 \%$ & $29 \%$ & $20 \%$ & $30 \%$ & $14 \%$ & 4195 & 4546 & $44 \%$ \\
\hline \multicolumn{9}{|l|}{$K y n^{* * *}$} \\
\hline Karl & $10 \%$ & $31 \%$ & $18 \%$ & $28 \%$ & $14 \%$ & 2114 & 2260 & $42 \%$ \\
\hline Kona & $5 \%$ & $26 \%$ & $22 \%$ & $33 \%$ & $14 \%$ & 2081 & 2286 & $47 \%$ \\
\hline \multicolumn{9}{|l|}{ Aldur ${ }^{* * *}$} \\
\hline 18-29 ára & $5 \%$ & $25 \%$ & $19 \%$ & $36 \%$ & $16 \%$ & 725 & 320 & $52 \%$ \\
\hline 30-44 ára & $7 \%$ & $33 \%$ & $20 \%$ & $31 \%$ & $9 \%$ & 1150 & 1091 & $40 \%$ \\
\hline 45-59 ára & $8 \%$ & $29 \%$ & $22 \%$ & $30 \%$ & $12 \%$ & 1182 & 1618 & $41 \%$ \\
\hline 60 ára og eldri & $9 \%$ & $27 \%$ & $18 \%$ & $26 \%$ & $20 \%$ & 1138 & 1517 & $46 \%$ \\
\hline \multicolumn{9}{|l|}{ Búseta*** } \\
\hline Höfuôborgarsvæð̋ & $8 \%$ & $30 \%$ & $18 \%$ & $30 \%$ & $13 \%$ & 2706 & 2897 & $44 \%$ \\
\hline Landsbyggð & $7 \%$ & $25 \%$ & $23 \%$ & $30 \%$ & $15 \%$ & 1482 & 1644 & $45 \%$ \\
\hline \multicolumn{9}{|l|}{ Menntun ${ }^{* * *}$} \\
\hline Grunnskólanám & $4 \%$ & $25 \%$ & $25 \%$ & $30 \%$ & $16 \%$ & 1031 & 387 & $47 \%$ \\
\hline Verklegt nám á framhaldsskólastigi & $9 \%$ & $27 \%$ & $18 \%$ & $30 \%$ & $16 \%$ & 842 & 1041 & $46 \%$ \\
\hline Bóklegt nám á framhaldsskólastigi & $6 \%$ & $27 \%$ & $22 \%$ & $31 \%$ & $14 \%$ & 724 & 538 & $46 \%$ \\
\hline Háskólanám & $10 \%$ & $34 \%$ & $16 \%$ & $30 \%$ & $11 \%$ & 1273 & 2254 & $40 \%$ \\
\hline \multicolumn{9}{|l|}{ Staða á vinnumarkaði*** } \\
\hline Tílaunuð̃u starfi & $7 \%$ & $29 \%$ & $20 \%$ & $32 \%$ & $12 \%$ & 2206 & 2631 & $44 \%$ \\
\hline Sjálfstætt starfandi / atvinnurekandi & $9 \%$ & $30 \%$ & $17 \%$ & $30 \%$ & $14 \%$ & 405 & 534 & $45 \%$ \\
\hline Í námi & $6 \%$ & $27 \%$ & $20 \%$ & $32 \%$ & $16 \%$ & 322 & 147 & $48 \%$ \\
\hline Annaỡ & $9 \%$ & $28 \%$ & $20 \%$ & $25 \%$ & $18 \%$ & 984 & 958 & $44 \%$ \\
\hline \multicolumn{9}{|l|}{ Tekjur einstaklings s** $^{\star 2}$} \\
\hline Lægri en 200 pús. kr. & $7 \%$ & $22 \%$ & $24 \%$ & $30 \%$ & $18 \%$ & 485 & 285 & $48 \%$ \\
\hline 201-300 pús. kr. & $6 \%$ & $27 \%$ & $19 \%$ & $30 \%$ & $18 \%$ & 559 & 463 & $48 \%$ \\
\hline 301-400 pús. kr. & $7 \%$ & $27 \%$ & $18 \%$ & $33 \%$ & $15 \%$ & 512 & 501 & $48 \%$ \\
\hline 401-600 pús. kr. & $7 \%$ & $31 \%$ & $20 \%$ & $31 \%$ & $11 \%$ & 969 & 1114 & $42 \%$ \\
\hline Hærri en 600 pús. kr. & $9 \%$ & $33 \%$ & $17 \%$ & $29 \%$ & $12 \%$ & 855 & 1265 & $41 \%$ \\
\hline \multicolumn{9}{|l|}{ Flokkur ef kosid yrđi á morgun ${ }^{\star * *}$} \\
\hline Björt framtiõ & $5 \%$ & $28 \%$ & $25 \%$ & $29 \%$ & $12 \%$ & 303 & 329 & $41 \%$ \\
\hline Framsóknarflokkur & $5 \%$ & $23 \%$ & $18 \%$ & $38 \%$ & $16 \%$ & 318 & 336 & $54 \%$ \\
\hline Viỡreisn & $6 \%$ & $29 \%$ & $19 \%$ & $33 \%$ & $13 \%$ & 339 & 381 & $46 \%$ \\
\hline Sjálfstæðisflokkur & $4 \%$ & $21 \%$ & $22 \%$ & $36 \%$ & $16 \%$ & 823 & 944 & $52 \%$ \\
\hline Samfylkingin & $18 \%$ & $33 \%$ & $16 \%$ & $23 \%$ & $11 \%$ & 208 & 276 & $34 \%$ \\
\hline Vinstrihreyfingin - grænt framboð & $9 \%$ & $34 \%$ & $16 \%$ & $28 \%$ & $14 \%$ & 813 & 937 & $41 \%$ \\
\hline Píratar & $9 \%$ & $33 \%$ & $18 \%$ & $27 \%$ & $14 \%$ & 465 & 435 & $41 \%$ \\
\hline Annar flokkur eða framboð & $14 \%$ & $33 \%$ & $13 \%$ & $23 \%$ & $17 \%$ & 215 & 201 & $40 \%$ \\
\hline
\end{tabular}


Рað er ýmislegt sem vekur athygli hér, p.e. í fyrsta lagi hversu hátt hlutfall Íslendinga er ekki meðvitað um pað að Ísland sé, í gegnum aðild sína að Atlantshafsbandalaginu, ekki hlutlaust land. Hins vegar er pað, að meirihluti kjósenda Sjálfstæðisflokks og Framsóknarflokks, sem styðja eindregið vestræna samvinnu á vettvangi Atlantshafsbandalagsins, taki undir pessa fullyrðingu. Pá vekur athygli að Píratar séu mun nær vinstriflokkunum tveim, en lítið hefur legið fyrir um utanríkisstefnu Pírata hingað til. Баð kemur einnig á óvart að um 41\% kjósenda Vinstrihreyfingarinnar - græns framboðs telja Ísland vera hlutlaust. Pessi samantekt sýnir að pað er áberandi misskilningur meðal almennings um pað hvað felst í aðild Íslands að Atlantshafsbandalaginu, og gefur ástæðu til að rannsaka betur hvort pað sé vegna pess að hugtökunum herleysi og hlutleysi sé blandað saman, eða hvort eitthvað annað liggi par til grundvallar. Pessi misskilningur getur skapað stjórnvöldum forsendur til að gera ráðstafanir varðandi hið ólíka mat almennings og stjórnvalda á öryggi Íslands sem kemur fram í svörum við öðrum spurningum í pessari könnun.

\section{2 Ógnir við öryggi Íslands}

Í könnuninni var spurt hvað pað væri sem pátttakendur teldu að ógnaði helst öryggi ríkisins og boðið upp á röðun ellefu atriða sem, eins og áður kom fram, voru fengin úr stærri eigindlegri rannsókn um viðhorf Íslendinga til öryggismála. 3.607 einstaklingar svöruðu pessari spurningu og par af röðuðu 3.266 öllum ellefu atriðunum. Í töflu 2 sést hvað svarendur settu í fyrsta sæti og varpar hún pví ljósi á pað hvaða atriði pað eru sem Íslendingar telja að ógni helst öryggi landsins. Раð er áberandi hvað umhverfismál koma fram ofarlega í pessari spurningu, en 25,8\% peirra sem svara telja að náttúruhamfarir séu helsta ógnin við ríkið og 21\% svarenda telur að pað sé umhverfisvá, eða samtals nærri helmingur peirra sem svara. Í kjölfarið fylgja svo fjármálakreppur og óstöðugleiki í efnahagsmálum (20,3\%), skipulögð glæpastarfsemi (11,2\%) og hryðjuverk (5,8\%). Pessi röðun sýnir vel að almenningur telur sér ekki stafa mikil ógn af skipulögðum aðgerðum gerenda á borð við hryðjuverkahópa eða önnur ríki. Einnig má ætla að almenningur telji umhverfislegt og félagslegt öryggi mikilvægara forgangsmál stjórnvalda en hernaðarlegt og pólitískt öryggi, par sem vopnuð átök og kjarnorkuvá eru talin mun ólíklegri ógnir. Einungis 1,8\% svarenda telja pessi atriði vera pau sem helst ógna öryggi ríkisins. Pá er sérstaklega áhugavert að prátt fyrir mikla fjölgun hryðjuverkaárása í nágrannalöndum (árásir í Frakklandi og Belgíu voru gerðar nokkrum mánuðum áður en könnunin var lögð fyrir) og verulega umfjöllun um pau í fjölmiðlum, pá settu einungis 31,6\% svarenda hryðjuverk í eitt af fimm efstu sætunum. Petta staðfestir einnig könnun Maskínu frá pví í mars 2017, en í henni sést að aðeins 8\% svarenda telja að hryðjuverk verði framin á landinu á meðan 76-77\% telja svo ekki verða, og ekki er munur á afstöðu eftir pví hvaða stjórnmálaflokk fólk styður. Tekjuhærri og meira menntaðir hópar telja minni líkur á hryðjuverkum og aðeins 4\% svarenda hugsa oft um að hryðjuverk verði framin á Íslandi, en peir sem hugsa oft um pað telja líklegra að svo verði (Maskína 2017). 
Tafla 2. Ógnir við öryggi ríkisins

Hvað telur pú helst ógna öryggi Íslands?

\begin{tabular}{lcccc}
\hline & Fjöldi & Hlutfall & Gilt hlutfall & Uppsafnađ hlutfall \\
\hline Náttúruhamfarir & 930 & 20,5 & 25,8 & 25,8 \\
Umhverfisvá og loftslagsbreytingar & 756 & 16,7 & 21 & 46,8 \\
Fjárhagslegt óöryggi/fjármálakreppa & 733 & 16,2 & 20,3 & 67,1 \\
Skipulögđ glæpastarfsemi & 404 & 8,9 & 11,2 & 78,3 \\
Hryðjuverk & 211 & 4,7 & 5,8 & 84,1 \\
Netárásir & 146 & 3,2 & 4,1 & 88,2 \\
Persónulegt ofbeldi & 106 & 2,3 & 2,9 & 91,1 \\
Fólksflutningar & 105 & 2,3 & 2,9 & 94 \\
Farsóttir og heimsfaraldur & 88 & 1,9 & 2,4 & 96,4 \\
Vopnuđ átök & 64 & 1,4 & 1,8 & 98,2 \\
Kjarnorkuvá & 64 & 1,4 & 1,8 & 100 \\
\hline Samtals & 3607 & 79,5 & 100 & \\
\hline Svarar ekki & 928 & 20,5 & & \\
Samtals & 4534 & 100 & &
\end{tabular}

\section{3 Ógnir við öryggi einstaklinga}

priðja spurningin um öryggismál varðaði ógnir við öryggi einstaklinga, en eins og fram kemur í fræðilegu yfirliti hefur áhersla rannsókna í alpjóðastjórnmálum færst í æ meiri mæli yfir á öryggi samfélaga og pað hvernig hversdagslegar aðstæður og ferli skapa öryggisógnir. Dessari spurningu svöruðu 3.197 einstaklingar, og 3.027 röðuðu öllum ellefu atriðunum 1 forgangsröð. Sami listinn var notaður hér og 1 spurningunni um öryggi ríkisins, einkum til að öðlast innsýn í pað að hve miklu leyti samfella væri á milli skynjunar almennings á eigin öryggi og öryggi ríkisins. Niðurstöðurnar eru nokkuð ápekkar, en pað er pó áberandi að efnahagskreppur og fjárhagslegur óstöðugleiki eru pað sem einstaklingar telja helst ógna sínu persónulega öryggi, en 37,5\% settu petta atriði í efsta sæti á meðan 18,7\% telja náttúruhamfarir helst ógna öryggi sínu og 16,1\% nefnir umhverfisvá. Dessir prír pættir eru pví pað sem 72,3\% eða nærri prír fjórðu hlutar almennings telja ógna sínu persónulega öryggi. Persónulegt ofbeldi er töluvert ofar hér en pegar spurt er um öryggi ríkisins, en rétt eins og í fyrri spurningu eru skipulögð glæpastarfsemi og hryðjuverk í 5.-6. sæti. Pá eru vopnuð átök og kjarnorkuvá jafnneðarlega á pessum lista og á peim fyrri, en einungis 1,7\% nefna fyrri páttinn og 1,5\% pann seinni sem helstu ógnina við sitt persónulega öryggi. 
Tafla 3. Ógnir við öryggi einstaklinga

Hvað telur pú skapa pér og fjölskyldu pinni hættu?

\begin{tabular}{lcccc}
\hline & Fjöldi & Hlutfall & Gilt hlutfall & Uppsafnað hlutfall \\
\hline Fjárhagslegt óöryggi/fjármálakreppa & 1199 & 26,4 & 37,5 & 37,5 \\
Náttúruhamfarir & 598 & 13,2 & 18,7 & 56,2 \\
Umhverfisvá og loftslagsbreytingar & 514 & 11,3 & 16,1 & 72,3 \\
Persónulegt ofbeldi & 196 & 4,3 & 6,1 & 78,4 \\
Skipulögð glæpastarfsemi & 169 & 3,7 & 5,3 & 83,7 \\
Hryđjuverk & 131 & 2,9 & 4,1 & 87,8 \\
Farsóttir og heimsfaraldur & 127 & 2,8 & 4 & 91,8 \\
Netárásir & 89 & 2 & 2,8 & 94,6 \\
Fólksflutningar & 70 & 1,6 & 2,2 & 96,8 \\
Vopnuð átök & 54 & 1,2 & 1,7 & 98,5 \\
Kjarnorkuvá & 50 & 1,1 & 1,5 & 100 \\
\hline Samtals & 3197 & 70,5 & 100 & \\
\hline Svarar ekki & 1337 & 29,5 & 100 &
\end{tabular}

\section{4 Рað sem tryggir öryggi ríkisins}

Í síðustu spurningunni sem fjallað er um hér voru pátttakendur beðnir að velja eitt atriði sem peir töldu helst tryggja öryggi ríkisins á alpjóðavettvangi og gátu peir valið á milli sex kosta. Alls svöruðu 4.008 pátttakendur og er marktækur munur á milli allra hópa ( $\mathrm{p}$ $<0,001)$. Hér var tilgangurinn að reyna að fá innsýn í skynjun almennings af pví hvaða alpjóðaskuldbindingar og/eða -tengsl tryggja helst öryggi íslenska ríkisins og pví ekki spurt um viðbrögð eða forvarnir gegn náttúruhamförum eða umhverfisvá. Valkostirnir, eins og kemur fram að framan, voru byggðir á viðbrögðum pátttakenda í stórri eigindlegri rannsókn og sóttir í forgangsröðun stjórnmálamanna í umræðum um öryggismál á Alpingi (Ómarsdóttir 2017). Deir voru: herleysi, friðsamleg tengsl við nágrannaríki, smæð ríkisins og að pað ógni engum, aðild að Atlantshafsbandalaginu, önnur vestræn samvinna og að lokum aðild að Schengen-samstarfinu.

Eins og sjá má í töflu 4 eru niðurstöðurnar afgerandi, en $41 \%$ svarenda telur að friðsamleg tengsl Íslands við nágrannaríki sín sé pað sem helst tryggir öryggi ríkisins. Mun færri telja önnur atriði hafa úrslitaáhrif, en pó ber að nefna að prjú atriði eru nær jöfn í öðru sæti, p.e. smæð ríkisins, herleysi pess og aðild að Atlantshafsbandalaginu, en 16-17\% - eða 50\% í heild - nefna hvert pessara atriða. Hins vegar nefna aðeins 7\% aðra vestræna samvinnu sem helstu tryggingu fyrir öryggi ríkisins. Pessi valkostur átti að draga fram hugmyndir um mikilvægi tengsla við Evrópusambandið fyrir öryggi landsins. Hér skera kjósendur Samfylkingarinnar sig úr, par sem 14\% peirra nefna petta atriði. Að lokum er aðeins $1 \%$ sem telur að Schengen-samstarfið sé mikilvægasta tryggingin fyrir öryggi ríkisins. 
Degar nánar er rýnt í svör við pessari spurningu kemur ýmislegt áhugavert í ljós. Í fyrsta lagi má nefna áberandi mun á milli kynjanna, en karlar og konur hafa augljóslega ólíka sýn á mikilvægi hernaðarbandalaga og friðsamlegra tengsla. Pannig telja 18\% kvenna að herleysi sé pað sem einkum tryggir öryggi ríkisins, en einungis 14\% karla eru peirrar skoðunar. Til viðbótar telja 43\% kvenna að friðsamleg tengsl við nágrannaríki séu helsta öryggistrygging landsins, en 38\% karla. Á móti kemur að einungis 11\% kvenna telja aðild að Atlantshafsbandalaginu skipta mestu máli í pessu samhengi, en 24\% karla eða nærri fjórðungur. Pá skilja prjú prósentustig að mat kvenna og karla á mikilvægi smæðar landsins; 19\% kvenna telja hana tryggja öryggi ríkisins en 16\% karla.

Rétt eins og pegar spurt var um meint hlutleysi ríkisins hefur yngri kynslóðin minnsta trú á mikilvægi aðildar að Atlantshafsbandalaginu. Aðeins 8\% peirra sem eru undir prítugu telja aðildina mikilvægustu öryggistrygginguna, en 21\% hefur pá skoðun á herleysi, áberandi hærra hlutfall en í heildarúrtakinu. Trú á mikilvægi Atlantshafsbandalagsins eykst pó með aldri og 25\% peirra sem eru yfir sextugu hafa mesta trú á aðild að pví. Í sama aldurshópi er pó mest traust (44\%) á mikilvægi friðsamlegra tengsla við nágrannaríki.

Menntun hefur lítið forspárgildi hvað varðar afstöðu til Atlantshafsbandalagsaðildar, en námsmenn höfðu frekar efasemdir um mikilvægi hennar fyrir öryggi landsins (10\%) á meðan 17\% launafólks og fólks í eigin rekstri treystu á hana. Hins vegar er fylgni milli hærri tekna og pess að telja Atlantshafsbandalagið skipta mestu máli fyrir öryggi ríkisins, en 23\% peirra í hæsta launaflokknum settu aðild að pví í fyrsta sæti og 19\% stjórnenda. Hið gagnstæða átti svo við um mikilvægi herleysis, par sem peir tekjulægstu forgangsröðuðu pví (20\%) en aðeins 13\% hinna tekjuhæstu.

Töluverður munur er á pví hvernig kjósendur stjórnmálaflokkanna svara pessari spurningu. Augljós gjá er á milli vinstri og hægri hvað varðar sýn á öryggismál. Einungis 7\% peirra sem kjósa Vinstrihreyfinguna - grænt framboð telja Atlantshafsbandalagsaðild skipta mestu máli fyrir öryggi ríkisins en 32\% kjósenda Sjálfstæðisflokksins. Mestur munur er á pessum tveimur hópum, en 16\% kjósenda Samfylkingarinnar og Bjartrar framtíðar eru sama sinnis, 21\% kjósenda Viðreisnar og 22\% kjósenda Framsóknarflokksins.

Kjósendur flestra stjórnmálaflokka eru sammála pví að friðsamleg tengsl við nágrannaríki skipti miklu fyrir öryggi ríkisins. Kjósendur á vinstri vængnum eru afgerandi fleiri par á meðal, en 47\% stuðningsmanna Vinstri grænna og Samfylkingarinnar telja svo vera. Flestir aðrir flokkar eru svo í hnapp í kringum 40\%; 40\% kjósenda Pírata, 39\% kjósenda Framsóknar, 38\% kjósenda Bjartrar framtíðar og 37\% kjósenda Sjálfstæðisflokksins. Kjósendur Viðreisnar skera sig svo úr á hinum endanum, en aðeins $30 \%$ peirra telja að friðsamleg tengsl við nágrannaríki skipti mestu fyrir öryggi íslenska ríkisins. Petta pýðir að stuðningsmenn Viðreisnar hafa langminnsta trú á pví að pau tvö atriði sem flestir telja skipta máli geri pað í raun og veru, en pað eru friðsamleg tengsl og herleysi ríkisins. Í heild telja aðeins $42 \%$ kjósenda Viðreisnar að petta tryggi helst öryggi ríkisins, en 48\% kjósenda Sjálfstæðisflokksins, sem pó hefur oftast verið hallastur undir hernaðarlega nálgun að öryggismálum á Íslandi. 
Kjósendur Viðreisnar skera sig einnig úr, reyndar með kjósendum Bjartrar framtíðar, hvað varðar sýn peirra á mikilvægi smæðar ríkisins. $26 \%$ kjósenda beggja flokka telja smæðina, og par af leiðandi pað að ríkið ógnar engum öðrum, vera pað sem helst tryggir öryggi landsins. Detta er mun hærra hlutfall en sjá má hjá kjósendum annarra flokka, en 16\% kjósenda Framsóknar, Sjálfstæðisflokks og Vinstri grænna er pessa sinnis, 17\% kjósenda Pírata en einungis 7\% kjósenda Samfylkingarinnar.

Loks er rétt að nefna pann mun sem birtist í svörum við spurningunni um herleysi Íslands og mikilvægi pess fyrir öryggi. bess hefði mátt vænta að mikill munur væri á milli

Tafla 4. Hvað tryggir helst öryggi Íslands

Hvað telur pú að̃ tryggi helst öryggi landsins?

\begin{tabular}{|c|c|c|c|c|c|c|c|c|c|}
\hline & Herleysi & $\begin{array}{c}\text { Friơsamleg } \\
\text { tengsl viơ } \\
\text { nágrannaríki }\end{array}$ & $\begin{array}{l}\text { Smæð̃ } \\
\text { landsins } \\
\text { (pað̃ ógnar } \\
\text { engum) }\end{array}$ & $\begin{array}{c}\text { Aỡild aố } \\
\text { NATO }\end{array}$ & $\begin{array}{l}\text { Vestræn } \\
\text { samvinna } \\
\text { (önnur en á } \\
\text { vettvangi } \\
\text { NATO) }\end{array}$ & $\begin{array}{l}\text { Schengen- } \\
\text { samstarfiô }\end{array}$ & $\begin{array}{c}\text { Fjöldi } \\
\text { eftir } \\
\text { vigtun }\end{array}$ & $\begin{array}{l}\text { Fjöldi } \\
\text { fyrir } \\
\text { vigtun }\end{array}$ & Herleysi eða friðsamleg tengsl \\
\hline Heild & $16 \%$ & $41 \%$ & $17 \%$ & $17 \%$ & $7 \%$ & $1 \%$ & 3645 & 4008 & $57 \%$ \\
\hline Kona & $18 \%$ & $43 \%$ & $19 \%$ & $11 \%$ & $8 \%$ & $1 \%$ & 1774 & 1969 & $62 \%$ \\
\hline \multicolumn{10}{|l|}{ Aldur $r^{\star * *}$} \\
\hline 18-29 ára & $21 \%$ & $40 \%$ & $24 \%$ & $8 \%$ & $7 \%$ & $1 \%$ & 668 & 285 & $60 \%$ \\
\hline 30-44 ára & $14 \%$ & $39 \%$ & $25 \%$ & $14 \%$ & $7 \%$ & $2 \%$ & 1003 & 959 & $53 \%$ \\
\hline 45-59 ára & $18 \%$ & $40 \%$ & $14 \%$ & $20 \%$ & $6 \%$ & $2 \%$ & 994 & 1417 & $58 \%$ \\
\hline Landsbyggð & $17 \%$ & $43 \%$ & $18 \%$ & $15 \%$ & $6 \%$ & $1 \%$ & 1256 & 1429 & $60 \%$ \\
\hline \multicolumn{10}{|l|}{ Menntun *** } \\
\hline Grunnskólanám & $17 \%$ & $42 \%$ & $16 \%$ & $19 \%$ & $5 \%$ & $1 \%$ & 870 & 324 & $59 \%$ \\
\hline Verklegt nám á framhaldsskólastigi & $16 \%$ & $44 \%$ & $14 \%$ & $20 \%$ & $5 \%$ & $1 \%$ & 764 & 943 & $60 \%$ \\
\hline Bóklegt nám á framhaldsskólastigi & $19 \%$ & $36 \%$ & $22 \%$ & $14 \%$ & $9 \%$ & $1 \%$ & 677 & 502 & $55 \%$ \\
\hline Háskólanám & $14 \%$ & $39 \%$ & $18 \%$ & $18 \%$ & $10 \%$ & $1 \%$ & 1180 & 2084 & $54 \%$ \\
\hline \multicolumn{10}{|l|}{ Stađa á vinnumarkaði*** } \\
\hline Í launuð̋u starfi & $16 \%$ & $40 \%$ & $19 \%$ & $17 \%$ & $7 \%$ & $2 \%$ & 1972 & 2385 & $56 \%$ \\
\hline Sjálfstætt starfandi / atvinnurekandi & $17 \%$ & $40 \%$ & $16 \%$ & $17 \%$ & $9 \%$ & $1 \%$ & 376 & 506 & $57 \%$ \\
\hline Í námi & $25 \%$ & $36 \%$ & $24 \%$ & $10 \%$ & $6 \%$ & $0 \%$ & 308 & 137 & $61 \%$ \\
\hline Hærri en 600 pús. kr. & $13 \%$ & $37 \%$ & $18 \%$ & $23 \%$ & $8 \%$ & $1 \%$ & 786 & 1169 & $50 \%$ \\
\hline \multicolumn{10}{|l|}{ Flokkur ef kosið yrđi á morgun ${ }^{* * *}$} \\
\hline Björt framtíð & $13 \%$ & $38 \%$ & $26 \%$ & $16 \%$ & $7 \%$ & $1 \%$ & 279 & 303 & $51 \%$ \\
\hline Framsóknarflokkur & $16 \%$ & $39 \%$ & $16 \%$ & $22 \%$ & $6 \%$ & $1 \%$ & 286 & 311 & $55 \%$ \\
\hline Viőreisn & $12 \%$ & $30 \%$ & $26 \%$ & $21 \%$ & $10 \%$ & $2 \%$ & 310 & 352 & $42 \%$ \\
\hline Sjálfstæððisflokkur & $11 \%$ & $37 \%$ & $16 \%$ & $32 \%$ & $4 \%$ & $1 \%$ & 736 & 861 & $48 \%$ \\
\hline Samfylkingin & $15 \%$ & $47 \%$ & $7 \%$ & $16 \%$ & $14 \%$ & $2 \%$ & 186 & 255 & $62 \%$ \\
\hline Vinstrihreyfingin - grænt framboð & $21 \%$ & $47 \%$ & $16 \%$ & $7 \%$ & $9 \%$ & $1 \%$ & 748 & 862 & $67 \%$ \\
\hline Piratar & $20 \%$ & $40 \%$ & $17 \%$ & $13 \%$ & $9 \%$ & $1 \%$ & 433 & 403 & $60 \%$ \\
\hline Annar flokkur eða framboð & $21 \%$ & $40 \%$ & $15 \%$ & $17 \%$ & $7 \%$ & $1 \%$ & 187 & 177 & $61 \%$ \\
\hline
\end{tabular}


vinstri og hægri í svörum við pessari spurningu, en reyndin er hins vegar sú að pað eru kjósendur Vinstri grænna og Pírata sem skera sig úr, en 21\% kjósenda hinna fyrrnefndu telur herleysi helstu trygginguna á öryggi landsins og 20\% kjósenda Pírata. Vinstrihreyfingin - grænt framboð er eini stjórnmálaflokkurinn á landinu sem tekur skýra afstöðu gegn aðild að Atlantshafsbandalaginu og margir kjósendur flokksins eru einnig virkir í Samtökum hernaðarandstæðinga, svo pessi afstaða fellur vel að bæði stefnu flokksins og ásýnd. Stefna Pírata í utanríkismálum er hins vegar ekki jafnskýrt mörkuð og pví óljóst hvort petta eru óbein tengsl eða afleiðing af pví að kjósendur samsami sig stefnu flokksins. Umtalsvert lægra hlutfall kjósenda Samfylkingar og Framsóknarflokks telur herleysi mikilvægast, eða 15\% og 16\% um sig. Kjósendur hægri flokkanna eru síðan á lægri endanum; 13\% kjósenda Bjartrar framtíðar, 12\% kjósenda Viðreisnar og 11\% kjósenda Sjálfstæðisflokksins telja herleysi tryggja öryggi ríkisins. Hér er loks rétt að nefna að peir sem segjast myndu kjósa aðra eða ótilgreinda flokka eru næst kjósendum Vinstri grænna og Pírata, eða 20\%. Petta kann að skýrast af pví að pað eru mun fleiri litlir flokkar á vinstri vængnum.

Svör við pessari spurningu gefa til kynna að Íslendingar hafi mikla trú á alpjóðasamskiptum, mikilvægi friðsamlegra tengsla og herleysi Íslands. Engu að síður er verulegur munur milli hópa og er hann mest áberandi pegar niðurstöðurnar eru skoðaðar í ljósi stuðnings við stjórnmálaflokka. Dennan mun má að mestu skýra á grundvelli ólíkra sjónarmiða vinstri- og hægriflokka, pótt einhverjar undantekningar megi einnig finna. Pá er einnig töluverður munur á milli kynjanna, og yngsta kynslóð pátttakenda sker sig úr hvað varðar traust á alpjóðasamvinnu og trú á mikilvægi friðsamlegra tengsla við nágrannaríki.

\subsection{Samantekt}

Hér hefur verið varpað ljósi á hugmyndir Íslendinga um utanríkis- og öryggismál, með hliðsjón af niðurstöðum könnunar sem er fyrsta skrefið í pví að byggja upp gagnabanka um próun pessara hugmynda á landinu. Spurningarnar voru mótaðar á grunni eigindlegrar rýnihóparannsóknar á skynjun almennings á öryggi sínu og ríkisins og í samvinnu við Félagsvísindastofnun Háskóla Íslands. Í fyrstu spurningunni sem var rædd hér voru pátttakendur beðnir að taka afstöðu til fullyrðingar um pað að Ísland væri hlutlaust í hernaðarmálum. Par kom í ljós að umtalsverður hluti pjóðarinnar er pessa sinnis og gefur pað til kynna að margir átti sig hvorki á pví að Ísland sé bundið af Atlantshafssáttmálanum né peim skuldbindingum sem honum fylgja. Afgerandi munur var á milli kjósenda vinstri og hægri flokka sem og milli kvenna og karla. Pá voru bæði yngstu og elstu pátttakendurnir líklegri en aðrir til að taka undir pessa fullyrðingu.

Í næstu tveim liðum könnunarinnar voru pátttakendur beðnir að taka afstöðu til pess hver af ellefu páttum ógnaði helst öryggi ríkisins annars vegar og öryggi peirra og fjölskyldna peirra hins vegar. Svörin hér gefa skýrt til kynna að almenningur telur enga hernaðarlega ógn steðja að Íslandi sem vert er að hafa áhyggjur af. Pá er lítill ótti við kjarnorkuvá sem og hryðjuverkaógn, prátt fyrir að alda hryðjuverka hafi gengið yfir nágrannalöndin á mánuðunum áður en könnunin var lögð fyrir. Hins vegar telur almenn- 
ingur öryggi sínu ógnað af efnahagslegum óstöðugleika, og öryggi ríkisins sérstaklega ógnað af náttúruhamförum og umhverfisvá.

Рá var farið yfir pað hvaða alpjóðaskuldbindingar almenningur telur að leggi mest til að tryggja öryggi ríkisins. Hér, rétt eins og pegar spurt var um hlutleysi, kom mikill munur í ljós sem skýra má á grundvelli stjórnmálaskoðana, en einnig varpaði pessi spurning ljósi á pað hve mikill munur er á skynjun kynjanna á eðli hinnar alpjóðlegu víddar. Niðurstöður könnunarinnar staðfesta niðurstöður fyrri rannsókna minna (Ómarsdóttir 2017), um að almenningur á Íslandi leggi mun meiri áherslu á umhverfis- og félagslegt öryggi en hefðbundið pólitískt og hernaðarlegt öryggi. Svipuð forgangsröðun birtist í pjóðaröryggisstefnu sem sampykkt var á Íslandi, en pó er áberandi að í fyrstu tillögum ráðherra er mun meiri áhersla á hernaðarlegt öryggi en umhverfis- og samfélagslegt. Breytingar sem gerðar voru í pinginu færðu stefnuna hins vegar nær hugmyndum almennings. Í næsta kafla verða pessar niðurstöður settar í samhengi við pá fræðilegu umræðu sem var kynnt í upphafi.

\section{Umræða og lokaorð}

Í pessari grein hefur verið farið yfir hugmyndir um öryggisgeira, öryggisvæðingu og verufræðilegt öryggi. Sú umræða hefur verið sett í samhengi við íslenskan veruleika í gegnum niðurstöður könnunar sem Félagsvísindastofnun Háskóla Íslands vann í lok árs 2016 og snerist um afstöðu til utanríkis- og öryggismála almennt. Par eru fjórar spurningar einkum til umræðu og snúa að hlutleysi og pví hvað ógnar öryggi annars vegar og tryggir pað hins vegar. Í pessum kafla verða pessar niðurstöður ræddar í samhengi við pá fræðilegu umgjörð sem kynnt var í upphafi.

Öryggisgeirar vísa til pess að öryggi nær yfir ólík svið samfélagsins, en slíkur skilningur mótaðist einkum eftir lok kalda stríðsins pegar teygðist á öryggishugtakinu og pað fór að vera notað yfir umhverfi, efnahag og samfélag, til viðbótar við hernað og stjórnmál (Buzan, Wæver \& deWilde 1998). Í könnun Félagsvísindastofnunar kom skýrt í ljós að almenningur á Íslandi lítur á öryggi í pessum breiða skilningi og telur helstu ógnir steðja að á öðrum sviðum en hinu hernaðarlega. Stjórnvöld hafa hins vegar tilhneigingu til að forgangsraða hernaðarlegu öryggi, eins og mátti sjá á tillögu utanríkisráðherra um pjóðaröryggisstefnu fyrir Ísland. Engu að síður nær umræða og stefnumótun um öryggi til allra pessara geira, og pingið virðist vera nær almenningi í sinni forgangsröðun. Einnig veitir pað framkvæmdavaldinu aðhald, eins og sást á peim breytingum sem voru gerðar áður en pjóðaröryggisstefna fyrir Ísland var sampykkt á pingi vorið 2016 (Vefútgáfa Alpingistíðinda 2016).

Öryggisvæðing á sér stað pegar gerendur setja fram hugmyndir sínar um ógnir og reyna að kalla eftir viðbrögðum við peim. Hugmyndirnar geta breyst milli ára og pað getur jafnvel gerst mjög hratt. Oftast eru pað valdhafar sem geta gert tilkall til pess að skilgreina ógnir, en öryggisvæðing heppnast pó ekki nema henni sé svarað og viðtakandi - oftast almenningur - taki ógnina til sín í gegnum annaðhvort málgjörð eða sjónrænar eða efnislegar athafnir. Öryggisvæðing er oft talin fara fram í gegnum valdastöðu pess sem reynir að koma henni í gegn og gjarnan pannig að krafa sé gerð um að pagga niður 
gagnrýna umræðu (McDonald 2008; Wæver 1998). Almenningur hefur sjaldnast stöðu til að öryggisvæða (Hansen 2000), svo hugmyndir almennings skila sér illa eða ekki inn í öryggisstefnu ríkja. Ógnir eru engu að síður breytilegar, eins og Sjöstedt (2013) bendir á og breytingar á t.d. pjóðaröryggisstefnu fyrir Ísland í meðförum pingsins sýna einmitt раð.

Eins og kemur fram í niðurstöðum kannananna sem hér eru lagðar til grundvallar töldu Íslendingar ekki að hryðjuverkaógn steðjaði að sér eða ríkinu á fyrrihluta árs. Pvert á móti var pað efnahagslegur óstöðugleiki og náttúruhamfarir sem flestir töldu helst ógna öryggi sínu. Efnahagslegu öryggi er ekki gefinn gaumur í pjóðaröryggisstefnu, og peim málefnum sem fella má undir umhverfis- og samfélagslegt öryggi var að mestu bætt inn á lokametrunum. Hefði svo ekki verið, mætti ætla að pjóðaröryggisstefnan hefði getað grafið undan verufræðilegu öryggi Íslendinga með pví að skapa óstöðugleika (Mitzen 2006). Afstaða Íslendinga til utanríkis- og öryggismála, eins og hún birtist hér, sýnir að sjálfsmynd peirra er af sér sem hlutlausri og friðsamlegri pjóð sem ógnar engum og stafar ekki ógn af neinum. Pessi sjálfsmynd hefur veikari stoðir í pjóðaröryggisstefnu ríkisins.

Í pessari grein hefur verið varpað ljósi á afstöðu Íslendinga til utanríkis- og öryggismála. Niðurstöður könnunarinnar sýna marktækan mun á milli hópa, en hér er pó aðeins sett fram lýsandi tölfræði. Markmiðið er enda ekki að álykta um pað hvort stjórnmálaskoðun, aldur eða menntun hafi áhrif á afstöðu fólks til öryggismála. Detta væri pó hægt að gera í frekari rannsóknum. Hér er um að ræða niðurstöður fyrstu könnunar á peirri afstöðu um nokkurt skeið og verður gagnlegt fyrir almenning og stjórnvöld að fylgjast með breytingum eftir pví sem árin líða, en ætlunin er að halda áfram að vinna pessa könnun reglulega héðan í frá. Eins og hér kemur fram telur stór hluti Íslendinga að friðsamleg tengsl við nágrannaríki og herleysi séu pað sem helst tryggir öryggi ríkisins, en Atlantshafsbandalagsaðild og önnur vestræn samvinna mun síður. Sú áhersla er mun meira áberandi í pjóðaröryggisstefnu ríkisins. Á grundvelli pessarar könnunar ættu stjórnvöld að geta fylgst með pví hvernig afstaða Íslendinga til utanríkis- og öryggismála próast og gætt pess að almenningur sé meðvitaður um pær forsendur sem áhættumat og öryggisstefna grundvallast á. Misræmi á milli stefnu og sjálfsmyndar getur grafið undan verufræðilegu öryggi Íslendinga. Til að forðast pað er pví pörf á að hleypa sjónarmiðum almennings að í stefnumótun.

\section{Heimildir}

Barnett, C. (2015). „On the milieu of security: Situating the emergence of new spaces of public action“, Dialogues in Human Geography 5(3), 257-270. doi:10.1177/2043820615607758

BBC News (2016). „Nice attack: What we know about the Bastille Day killings“. Sótt 19. ágúst 2017 af http://www.bbc.com/news/world-europe-36801671

Browning, C.S. og Joenniemi, P. (2017). „Ontological security, self-articulation and the securitization of identity", Cooperation and Conflict 52(1), 31-47. doi: 10.1177/0010836716653161

Buzan, B. (1991). People, states and fear: An agenda for international security studies in the post-cold war era (2. útg.). London: Harvester Wheatsheaf.

Buzan, B., Wxver, O. og de Wilde, J. (1998). Security: a new framework for analysis. Boulder, Co.: Lynne Rienner Publishers. 


\section{STJÓRNSÝSLA}

Centers for Disease Control and Prevention (2017). „Information on avian influenza“. Sótt af https:// www.cdc.gov/flu/avianflu/index.htm

Delehanty, W.K. og Steele, B.J. (2009). „Engaging the narrative in ontological (in)security theory: Insights from feminist IR“, Cambridge Review of International Affairs 22(3), 523-540. doi:10.1080/ 09557570903104024

Flockhart, T. (2012). ,Towards a strong NATO narrative: From a 'practice of talking' to a 'practice of doing"“, International Politics 49(1), 78-97. doi:10.1057/ip.2011.31

Giorgis, H. (2014). „The problem with the west's Ebola response is still fear of a black patient”, The Guardian. Sótt 16. október 2017 af https://www.theguardian.com/commentisfree/2014/oct/16/ west-ebola-response-black-patient

Hansen, L. (2000). „The little mermaid's silent security dilemma and the absence of gender in the Copenhagen school“, Millennium - Journal of International Studies 29(2), 285-306. doi:10.1177/03058298 000290020501

Hardarson, Ó.Th. (1985). „Icelandic security and foreign policy: The public attitude“, Cooperation and Conflict 20(4), 297-316.

Huysmans, J. (2011). „What's in an act? On security speech acts and little security nothings“, Security Dialogue 42(4-5), 371-383. doi:10.1177/0967010611418713

Íslenska kosningarannsóknin (e.d.). „Íslenska kosningarannsóknin“ [Icelandic National Election Study - ICENES]. Sótt af http://fel.hi.is/icelandic_national_election_study_icenes

Kinnvall, C. (2004). „Globalization and religious nationalism: Self, identity, and the search for ontological security“, Political Psychology 25(5), 741-767. doi:10.1111/j.1467-9221.2004.00396.x

Maskína (2017). „Fáir telja að hryðjuverk verði framin á Íslandi“. Sótt af http://maskina.is/images/2017_03_Hry\%C3\%B0juverk_Mask\%C3\%ADnuk\%C3\%B6nnun.pdf

mbl.is (2012). „Valgerður stýrir nefnd um pjóðaröryggi“, Mbl.is, 30. janúar. Sótt af http://www.mbl.is/ frettir/innlent/2012/01/30/valgerdur_styrir_nefnd_um_thjodaroryggi/

McDonald, M. (2008). „Securitization and the construction of security“, European Journal of International Relations 14(4), 563-587. doi:10.1177/1354066108097553

Mitzen, J. (2006). „Ontological security in world politics: State identity and the security dilemma“, European Journal of International Relations 12(3), 341-370. doi:10.1177/1354066106067346

Omoleke, S.A., Mohammed, I. og Saidu, Y. (2016). „Ebola viral disease in West Africa: A threat to global health, economy and political stability“, Journal of Public Health in Africa 7(1), 534. doi:10.4081/ jphia.2016.534

Ómarsdóttir, S.B. (2017). The security imaginaries of an unarmed people: Popular and elite discourses of security in Iceland (doktorsritgerð).University College Cork, Írland.

Ómarsdóttir, S.B. og Elínardóttir, J.S. (2010). L’Islande et l'Union européenne. Revue de l’Union européenne Oct-Nov(542), 9.

Sjöstedt, R. (2013). „Ideas, identities and internalization: Explaining securitizing moves“, Cooperation and Conflict 48(1), 143-164. doi:10.1177/0010836712445023

Steele, B.J. (2005). „Ontological security and the power of self-identity: British neutrality and the American civil war", Review of International Studies 31(3), 519-540.

Taureck, R. (2006). ,Securitization theory and securitization studies“, Journal of International Relations and Development 9(1), 53-61.

Utanríkisráduneyti Íslands (2009). Áhættumatsskýrsla fyrir Ísland: Hnattrænir, samfélagslegir og hernaðarlegir pættir. Reykjavík: Utanríkisráðuneytið

Van Rythoven, E. (2015). „Learning to feel, learning to fear? Emotions, imaginaries, and limits in the politics of securitization“, Security Dialogue 46(5), 458-475. doi:10.1177/0967010615574766

Vefútgáfa Alpingistíðinda (2016). „Djóðaröryggisstefna fyrir Ísland“. Sótt af https://www.althingi.is/ thingstorf/thingmalalistar-eftir-thingum/ferill/?ltg $=145 \& \mathrm{mnr}=327$

Wæver, O. (1998). „Securitization and Desecuritization“, í R.D. Lipschutz (ritstj.), On Security (p. 46-86). New York: Columbia University Press. 
